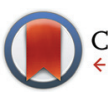

CrossMark \& click for updates

Cite this: Dalton Trans., 2016, 45 7385

Received 13th December 2015, Accepted 19th March 2016

DOI: $10.1039 / c 5 d t 04864 h$

www.rsc.org/dalton

\section{Transformation of zinc hydroxide chloride monohydrate to crystalline zinc oxide $\uparrow$}

\author{
Amir Moezzi, ${ }^{a, b}$ Michael Cortie ${ }^{\star b}$ and Andrew McDonagh ${ }^{b}$
}

Thermal decomposition of layered zinc hydroxide double salts provides an interesting alternative synthesis for particles of zinc oxide. Here, we examine the sequence of changes occurring as zinc hydroxide chloride monohydrate $\left(\mathrm{Zn}_{5}(\mathrm{OH})_{8} \mathrm{Cl}_{2} \cdot \mathrm{H}_{2} \mathrm{O}\right)$ is converted to crystalline $\mathrm{ZnO}$ by thermal decomposition. The specific surface area of the resultant $\mathrm{ZnO}$ measured by BET was $1.3 \mathrm{~m}^{2} \mathrm{~g}^{-1}$. A complicating and important factor in this process is that the thermal decomposition of zinc hydroxide chloride is also accompanied by the formation of volatile zinc-containing species under certain conditions. We show that this volatile compound is anhydrous $\mathrm{ZnCl}_{2}$ and its formation is moisture dependent. Therefore, control of atmospheric moisture is an important consideration that affects the overall efficiency of $\mathrm{ZnO}$ production by this process.

\section{Introduction}

Zinc oxide is an important industrial chemical that may be synthesized by a very wide variety of means. ${ }^{1}$ Calcination or pyrolysis of a suitable precursor, for example an alkylzinc alkoxide $^{2}$ or a basic zinc salt ${ }^{3}$ are amongst the many options. Here we consider the use of the basic salt 'zinc hydroxide chloride' as a precursor in this context. Since it was first reported in $1855,{ }^{4}$ the composition and decomposition of 'zinc hydroxide chloride' has been controversial. Many compositions and structures have been proposed for this compound, which has the general formula of $x \mathrm{Zn}(\mathrm{OH})_{2} \cdot y \mathrm{ZnCl}_{2} \cdot z \mathrm{H}_{2} \mathrm{O}$. Among the reported phases, $4 \mathrm{Zn}(\mathrm{OH})_{2} \cdot \mathrm{ZnCl}_{2} \cdot \mathrm{H}_{2} \mathrm{O}$ (often described as $\mathrm{Zn}_{5}(\mathrm{OH})_{8} \mathrm{Cl}_{2} \cdot \mathrm{H}_{2} \mathrm{O}$, basic zinc chloride or Simonkolleite, JC-PDF 01-077-2311), $\mathrm{ZnO} \cdot \mathrm{ZnCl}_{2} \cdot 2 \mathrm{H}_{2} \mathrm{O}$ (JC-PDF 00045-0819) and $\beta-\mathrm{Zn}(\mathrm{OH}) \mathrm{Cl}$ (JC-PDF 01-072-0525) appear to be the most stable. $\mathrm{Zn}_{5}(\mathrm{OH})_{8} \mathrm{Cl}_{2} \cdot \mathrm{H}_{2} \mathrm{O}$ is in the family of layered hydroxide double salts, also called 'anionic clays'. It possesses hydration/adsorption properties similar to those of natural clays whereby a large interlayer distance $(0.79 \mathrm{~nm})$ accommodates $\mathrm{H}_{2} \mathrm{O} / \mathrm{CO}_{2}$ in the interlayer void sites.

The thermal decomposition of $\mathrm{Zn}_{5}(\mathrm{OH})_{8} \mathrm{Cl}_{2} \cdot \mathrm{H}_{2} \mathrm{O}$ has been previously studied..$^{5-13}$ In general it is agreed that the process

\footnotetext{
${ }^{a}$ Avocado Engineering Pty. Ltd., NSW, Australia.

E-mail: a.moezzi@avocadoengineering.com; Tel: +61-422088578

${ }^{b}$ Institute for Nanoscale Technology, University of Technology Sydney, PO Box 123, Broadway, NSW 2007, Australia.E-mail: Michael.cortie@uts.edu.au; Tel: +61-2-9514-2208

$\dagger$ Electronic supplementary information (ESI) available: XRD and TGA data, additional SEM images, a schematic of the sublimation apparatus. See DOI: $10.1039 / \mathrm{c} 5 \mathrm{dt} 04864 \mathrm{~h}$
}

takes place in a sequence of steps, but there are differing views concerning the actual mechanism.

A two-step decomposition mechanism for $\mathrm{Zn}_{5}(\mathrm{OH})_{8} \mathrm{Cl}_{2} \cdot \mathrm{H}_{2} \mathrm{O}$ has been proposed ${ }^{5,6}$ involving initial decomposition to $\mathrm{ZnO}$ and $\mathrm{ZnCl}_{2}$ followed by melting and evaporation of $\mathrm{ZnCl}_{2}$. It was reported that $\beta-\mathrm{Zn}(\mathrm{OH}) \mathrm{Cl}$ also decomposes to $\mathrm{ZnO}$ and $\mathrm{ZnCl}_{2}$ in a similar manner. ${ }^{5,6}$ In contrast, a stepwise sequence of de-hydration reactions has been suggested ${ }^{7}$ in this scenario $\mathrm{Zn}_{5}(\mathrm{OH})_{8} \mathrm{Cl}_{2} \cdot \mathrm{H}_{2} \mathrm{O}$ decomposes to $\mathrm{ZnO}$ and $\mathrm{ZnO} \cdot \mathrm{ZnCl}_{2} \cdot 2 \mathrm{H}_{2} \mathrm{O}$ at $\sim 160{ }^{\circ} \mathrm{C}$, loses one water of hydration at $\sim 230{ }^{\circ} \mathrm{C}$ before, finally, the $\mathrm{ZnO} \cdot \mathrm{ZnCl}_{2} \cdot \mathrm{H}_{2} \mathrm{O}$ loses its remaining water together with $\mathrm{ZnCl}_{2}{ }^{7}$ In other studies of $\mathrm{Zn}_{5}(\mathrm{OH})_{8} \mathrm{Cl}_{2} \cdot \mathrm{H}_{2} \mathrm{O}$ heated to $1000{ }^{\circ} \mathrm{C}, \mathrm{Zn}(\mathrm{OH}) \mathrm{Cl}$ was reported as an intermediate, i.e. as the product of decomposition of $\mathrm{Zn}_{5}(\mathrm{OH})_{8} \mathrm{Cl}_{2} \cdot \mathrm{H}_{2} \mathrm{O}$, which may in turn convert to $\mathrm{ZnO}, \mathrm{ZnCl}_{2}$ and water between $210-300{ }^{\circ} \mathrm{C}$. The $\mathrm{ZnCl}_{2}$ formed is volatilised at temperatures above $300{ }^{\circ} \mathrm{C}$ and escapes from the system. ${ }^{8}$ Krunks et al. postulated ${ }^{10}$ that $\mathrm{Zn}_{5}(\mathrm{OH})_{8} \mathrm{Cl}_{2} \cdot \mathrm{H}_{2} \mathrm{O}$ decomposes to $\mathrm{ZnO} \cdot \mathrm{ZnCl}_{2} \cdot 2 \mathrm{H}_{2} \mathrm{O}$ followed by decomposition to $\mathrm{ZnO}$ and $\mathrm{ZnCl}_{2}$.

In contrast to the above, two recently proposed mechanisms do not involve the formation of $\mathrm{ZnCl}_{2}$ at all. ${ }^{12}$ Tanaka and Fujioka suggested a decomposition mechanism that included the formation of $\beta-\mathrm{Zn}(\mathrm{OH}) \mathrm{Cl}$ and $\mathrm{Zn}(\mathrm{OH})_{2}$ followed by complete decomposition of these two intermediates to $\mathrm{ZnO}$ and $\mathrm{HCl}$ and $\mathrm{H}_{2} \mathrm{O}$ at $225{ }^{\circ} \mathrm{C} .{ }^{12}$ (However, formation of $\mathrm{Zn}(\mathrm{OH})_{2}$ at such temperatures seems somewhat unlikely as it normally decomposes to $\mathrm{ZnO}$ at around 120 to $\left.130{ }^{\circ} \mathrm{C}\right) .{ }^{5,14,15}$ Similarly, Zhang and Yanagisawa suggested ${ }^{11}$ that $\mathrm{Zn}_{5}(\mathrm{OH})_{8} \mathrm{Cl}_{2} \cdot \mathrm{H}_{2} \mathrm{O}$ decomposes to only $\mathrm{ZnO}$ and $\mathrm{HCl}$ and water with the release of $\mathrm{HCl}$ in the last stage of the decomposition.

The proportion of the material that may be volatilised as $\mathrm{ZnCl}_{2}$ has a direct bearing on the mass loss associated with 
the decomposition. There are lower and upper limits: if all the $\mathrm{Cl}$ escapes from the reactor as $\mathrm{HCl}$ then $5 \mathrm{ZnO}$ is eventually formed for every mole of $\mathrm{Zn}_{5}(\mathrm{OH})_{8} \mathrm{Cl}_{2} \cdot \mathrm{H}_{2} \mathrm{O}$ and the mass loss is only $26.3 \%$. This case is equivalent to a situation in which no $\mathrm{ZnCl}_{2}$ is formed or, if $\mathrm{ZnCl}_{2}$ is formed, it is hydrolysed in situ to $\mathrm{ZnO}$. In contrast, if all $\mathrm{Cl}$ is converted to $\mathrm{ZnCl}_{2}$, which then all escapes by evaporation, then only $4 \mathrm{ZnO}$ remains in the reactor and the mass loss is $41.02 \%$.

A common problem in thermogravimetric analysis (TGA) studies of $\mathrm{Zn}_{5}(\mathrm{OH})_{8} \mathrm{Cl}_{2} \cdot \mathrm{H}_{2} \mathrm{O}$ is that the overall mass loss observed after decomposition to $\mathrm{ZnO}$ is somewhat variable, with reported values being in the range 25.5 to $37.5 \% .^{5,8,9,12,13}$ These discrepancies are attributed to the partial hydrolysis of $\mathrm{ZnCl}_{2}$ to form $\mathrm{ZnO}$. For example, Garcia-Martinez et al., suggested that $\beta-\mathrm{Zn}(\mathrm{OH}) \mathrm{Cl}$ and $\mathrm{ZnCl}_{2}$ are formed as intermediate products during the decomposition of $\mathrm{Zn}_{5}(\mathrm{OH})_{8} \mathrm{Cl}_{2} \cdot \mathrm{H}_{2} \mathrm{O}$ followed by hydrolysis of a portion of the $\mathrm{ZnCl}_{2}$ to form $\mathrm{ZnO}$ and $\mathrm{HCl}^{9}{ }^{9}$ Recently, Kozawa et al., examined the thermal decomposition of $\mathrm{Zn}_{5}(\mathrm{OH})_{8} \mathrm{Cl}_{2} \cdot \mathrm{H}_{2} \mathrm{O}$ and examined the hypothesis that water vapour in the calcination atmosphere was the factor responsible for these variable losses. TGA-DTA experiments up to $520^{\circ} \mathrm{C}$ were conducted in air, dry $\mathrm{N}_{2}$ and humid $\mathrm{N}_{2}$ with $\mathrm{P}_{\left(\mathrm{H}_{2} \mathrm{O}\right)}$ of 4.5 and $10 \mathrm{kPa}$. They confirmed that mass loss is a function of the partial pressure of water. A $37.5 \%$ mass loss under dry-condition experiments was attributed to the formation of volatile $\mathrm{ZnCl}_{2}$, whereas under humid conditions, mass loss was close to the theoretical lower limit of $26.3 \% .^{13}$

Disparities in the suggested mechanisms appear to arise mainly because of the more-than-expected mass loss observed in TGA experiments and confusing DTA data. The observation that $\mathrm{Zn}_{5}(\mathrm{OH})_{8} \mathrm{Cl}_{2} \cdot \mathrm{H}_{2} \mathrm{O}$ was almost free of unbound moisture in the studies discussed above led to conclusions that the excess mass loss (relative to the theoretical value of $26.3 \%$ for the complete conversion to only $\mathrm{ZnO}$ ) is related to volatile compounds other than water and $\mathrm{HCl}$, such as $\mathrm{ZnCl}_{2}$. Nevertheless, there is scant direct experimental evidence that $\mathrm{ZnCl}_{2}$ is involved, either as an intermediate or final product.

In the work presented here, we re-examine the phase transformations, crystalline intermediate phases and gases evolved during thermal decomposition of $\mathrm{Zn}_{5}(\mathrm{OH})_{8} \mathrm{Cl}_{2} \cdot \mathrm{H}_{2} \mathrm{O}$ using a combination of TGA-DTA (thermogravimetric analysis-differential thermal analysis), TGA-MS (TGA-mass spectrometry) and in situ real-time synchrotron radiation XRD. The evolution of volatile and hydroscopic zinc-containing compounds during the thermal decomposition of $\mathrm{Zn}_{5}(\mathrm{OH})_{8} \mathrm{Cl}_{2} \cdot \mathrm{H}_{2} \mathrm{O}$ is confirmed and the identity of the volatile materials is clarified.

\section{Experimental}

\section{General}

Zinc chloride and zinc oxide powder (AR grade) were purchased from Ajax Chemicals and used as received. MilliQ water (18.2 $\mathrm{M} \Omega \mathrm{cm}^{-1}$ ) was used as solvent. Reactions were conducted under atmospheric conditions using a two-neck round bottom flask with a digitally-controlled magnetic heater/ stirrer. A magnetic stirrer bar was used at a stirring rate of 500 $\mathrm{rpm}$ and isolation of the precipitates was performed by vacuum filtration followed by drying using a rotary evaporator at $70{ }^{\circ} \mathrm{C}$.

Synchrotron powder XRD studies were conducted at the Australian Synchrotron using $0.3 \mathrm{~mm}$ diameter silica capillaries filled with sample. The X-ray wavelength was set at $0.696603 \AA$ (confirmed by refinement on $\mathrm{a} \mathrm{LaB}_{6}$ standard). The time stamp corresponded to the beginning of each two-minute collection interval and the sample was ramped at $5 \mathrm{~K} \mathrm{~min}^{-1}$. $3 \mathrm{D}$ and color-coded contour graphs were generated using MATLAB version 7, which was also used for numerical analysis. Intensity data were corrected by division of the intensity figure by the integrated ion chamber count figure multiplied by $1 \times 10^{5}$ to form an arbitrary unit.

$\mathrm{X}$-ray diffraction experiments using powder samples were also performed using a laboratory Siemens D5000 X-ray diffractometer with a graphite post monochromator with the following parameters: wavelength $0.15406 \mathrm{~nm}(\mathrm{Cu} \mathrm{K \alpha})$, tube power $1.6 \mathrm{~kW}(40 \mathrm{kV}$ at $40 \mathrm{~mA})$, step size $=0.02^{\circ}$, time per step $=2 \mathrm{~s}$, divergent slit $=1^{\circ}$, receiving slit $=0.02 \mathrm{~mm}$, scan angle range $=3-80^{\circ}$. Scanning electron microscopy images were obtained using a Zeiss Supra 55VP SEM operating in high vacuum mode. An accelerating voltage of $5-20 \mathrm{kV}$ was used with 10-30 $\mu \mathrm{m}$ aperture and images were obtained using an in-lens secondary detector. Thermogravimetric analysis (TGA) experiments were performed using TA Instruments-SDT 2960 with simultaneous DTA-TGA. A heating rate of $5 \mathrm{~K} \mathrm{~min}^{-1}$ was used in air atmosphere.

Simultaneous thermogravimetric analysis-mass spectrometry (TGA-MS) experiments were conducted using a Quadrupole mass spectrometer (model: Thermostar QMS 200 M3) from Balzers Instruments in a platinum crucible. Heating rates of 3 and $4 \mathrm{~K} \mathrm{~min}^{-1}$ and environments of air and argon were applied. The ion intensities associated with the following masses were examined: $\mathrm{H}_{2} \mathrm{O}: 18, \mathrm{HCl}: 36, \mathrm{CO}_{2}: 44$ and $I_{136}$ for $\mathrm{ZnCl}_{2}: 136$. BET specific surface area measurement was performed using Autosorb-1 from Quantachrome Instrument by the precise vacuum volumetric method for nitrogen chemisorption. Multi-point (5 points) measurement was conducted on the sample.

\section{Synthesis of zinc hydroxide chloride hydrate $\left(\mathrm{Zn}_{5}(\mathrm{OH})_{8} \mathrm{Cl}_{2} \cdot \mathrm{H}_{2} \mathrm{O}\right)$}

An aqueous solution of $\mathrm{ZnCl}_{2}(24.42 \mathrm{~g}$ in $30 \mathrm{~mL}, 6 \mathrm{M}, \mathrm{pH}=3$ ) was added to a suspension of $\mathrm{ZnO}(14.65 \mathrm{~g}, 0.18 \mathrm{~mol})$ in water $(70 \mathrm{~mL})$ in a single step at $90{ }^{\circ} \mathrm{C}$. The mixture was stirred for 2 hours after which time the $\mathrm{pH}$ was 7 . The resultant white suspension was filtered, washed with water and dried. The sample was stable during storage for over a year under ambient conditions (ESI, Fig. S1†).

\section{Synthesis of zinc oxide from zinc hydroxide chloride hydrate}

Zinc hydroxide chloride hydrate was calcined in a preheated oven. Samples were examined by XRD after each of the 
following three stages: (1) at $400{ }^{\circ} \mathrm{C}$ for 2 hours; (2) at $400{ }^{\circ} \mathrm{C}$ for an extra 4 hours and (3) at $600{ }^{\circ} \mathrm{C}$ for 4 hours. After each stage, the product was cooled to room temperature in air. The $\mathrm{ZnO}$ sample produced by calcining at $600{ }^{\circ} \mathrm{C}$ was stable during storage for over a year under ambient conditions (ESI, Fig. S2 $\dagger$ ).

Sublimation experiments were performed using a cold finger sublimation apparatus heated to $\sim 450{ }^{\circ} \mathrm{C}$ in vacuo. $\mathrm{Zn}_{5}(\mathrm{OH})_{8} \mathrm{Cl}_{2} \cdot \mathrm{H}_{2} \mathrm{O}$ was first dehydrated in a preheated oven at $300{ }^{\circ} \mathrm{C}$ for 1 hour and the resultant white powder transferred to the sublimation apparatus and heated to $450{ }^{\circ} \mathrm{C}$. The white powder became green-yellow in colour. A condensate formed on the water-cooled core but disappeared after a short time while off-white crystals formed on the wall of the vessel. These crystals could be melted by additional heat (heat gun) and reformed by removing the additional heat. After cooling, the crystalline sublimate, which was quite hygroscopic, was collected.

\section{Results and discussion}

The powder XRD pattern of the $\mathrm{Zn}_{5}(\mathrm{OH})_{8} \mathrm{Cl}_{2} \cdot \mathrm{H}_{2} \mathrm{O}$ is shown in Fig. 1(a). The peaks associated with the as-synthesized material correspond to those previously reported for this compound (JC-PDF: 01-077-2311). Calcination of $\mathrm{Zn}_{5}(\mathrm{OH})_{8} \mathrm{Cl}_{2} \cdot \mathrm{H}_{2} \mathrm{O}$ in air at $400{ }^{\circ} \mathrm{C}$ yielded $\mathrm{ZnO}$ as well as $\mathrm{ZnO} \cdot \mathrm{ZnCl}_{2} \cdot 2 \mathrm{H}_{2} \mathrm{O}$ (JC-PDF: 00-045-0819), Fig. 1(b). The intensity of the peaks associated with $\mathrm{ZnO} \cdot \mathrm{ZnCl}_{2} \cdot 2 \mathrm{H}_{2} \mathrm{O}$ decreased after 6 hours of calcination at $400{ }^{\circ} \mathrm{C}$, but conversion to $\mathrm{ZnO}$ was still incom-

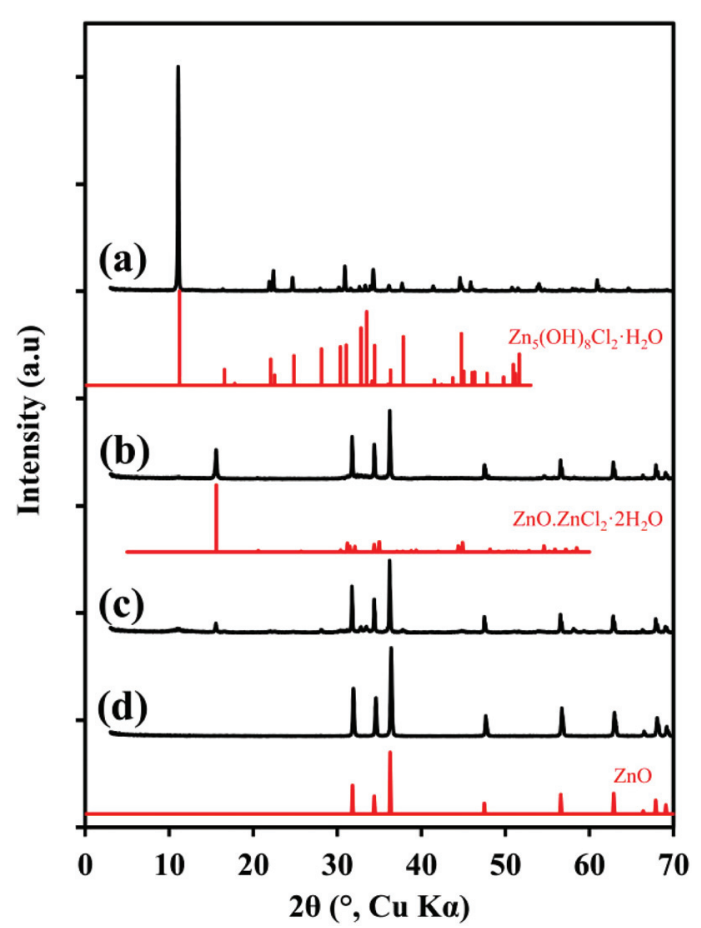

Fig. 1 Powder XRD data for (a) $\mathrm{Zn}_{5}(\mathrm{OH})_{8} \mathrm{Cl}_{2} \cdot \mathrm{H}_{2} \mathrm{O}$; (b) calcined $\mathrm{Zn}_{5}(\mathrm{OH})_{8} \mathrm{Cl}_{2} \cdot \mathrm{H}_{2} \mathrm{O}$ for 2 hours at $400{ }^{\circ} \mathrm{C}$; (c) calcined $\mathrm{Zn}_{5}(\mathrm{OH})_{8} \mathrm{Cl}_{2} \cdot \mathrm{H}_{2} \mathrm{O}$ for 6 hours at $400{ }^{\circ} \mathrm{C}$ and (d) calcined $\mathrm{Zn}_{5}(\mathrm{OH})_{8} \mathrm{Cl}_{2} \cdot \mathrm{H}_{2} \mathrm{O}$ for 6 hours at $400{ }^{\circ} \mathrm{C}$ plus 4 hours at $600^{\circ} \mathrm{C}$. plete after this time with small peaks associated with $\mathrm{Zn}_{5}(\mathrm{OH})_{8} \mathrm{Cl}_{2} \cdot \mathrm{H}_{2} \mathrm{O}$ still visible, Fig. 1(c). This behaviour has been reported by others although the intermediate phase in those instances was identified as $\beta-\mathrm{Zn}(\mathrm{OH}) \mathrm{Cl}^{13}$ After calcination at $600{ }^{\circ} \mathrm{C}$ for 4 hours, only peaks assigned to $\mathrm{ZnO}$ (JC-PDF: 01-075-0576) were evident in the XRD data, Fig. 1(d).

The BET specific surface area of the $\mathrm{ZnO}$ produced by calcination of the $\mathrm{Zn}_{5}(\mathrm{OH})_{8} \mathrm{Cl}_{2} \cdot \mathrm{H}_{2} \mathrm{O}$ to $600{ }^{\circ} \mathrm{C}$ was $1.3 \mathrm{~m}^{2} \mathrm{~g}^{-1}$, which is lower than that of $\mathrm{ZnO}$ prepared by the common industrial French process $\left(\sim 3-5 \mathrm{~m}^{2} \mathrm{~g}^{-1}\right)^{1}$ or by direct wetchemistry precipitation techniques $\left(\sim 10-33 \mathrm{~m}^{2} \mathrm{~g}^{-1}\right)^{15}$ or from decomposition of zinc hydroxide acetate $\left(15.4 \mathrm{~m}^{2} \mathrm{~g}^{-1}\right)^{16}$ or from decomposition of zinc hydroxide carbonate (47-65 $\mathrm{m}^{2}$ $\left.\mathrm{g}^{-1}\right),{ }^{1}$ but is similar to that reported for the grade of $\mathrm{ZnO}$ produced by the 'American' process ${ }^{1}$ and to $\mathrm{ZnO}$ made by thermal decomposition of zinc hydroxide sulfate $\left(\sim 0.7 \mathrm{~m}^{2} \mathrm{~g}^{-1}\right) .{ }^{17} \mathrm{SEM}$ images of $\mathrm{Zn}_{5}(\mathrm{OH})_{8} \mathrm{Cl}_{2} \cdot \mathrm{H}_{2} \mathrm{O}$ and the $\mathrm{ZnO}$ particles prepared from it are shown in Fig. 2 (additional images are shown in the ESI, Fig. S3 $\dagger$ ). The $\mathrm{Zn}_{5}(\mathrm{OH})_{8} \mathrm{Cl}_{2} \cdot \mathrm{H}_{2} \mathrm{O}$ morphology is platelike with micron-sized crystals whereas the subsequent $\mathrm{ZnO}$ crystal size is $200 \mathrm{~nm}$ to $1 \mu \mathrm{m}$ and more spherical in shape.

TGA-DTA was performed on samples of $\mathrm{Zn}_{5}(\mathrm{OH})_{8} \mathrm{Cl}_{2} \cdot \mathrm{H}_{2} \mathrm{O}$ prepared in the same batch but measured on separate occasions. In both cases a heating rate of $5 \mathrm{~K} \mathrm{~min}^{-1}$ was used in air atmosphere but the results, shown in Fig. 3, are significantly different. The total mass loss of sample (I) is $\sim 26.5 \%$ and that of sample (II) is $31.5 \%$. At temperatures less than $100{ }^{\circ} \mathrm{C}$, almost no mass loss occurs in either sample indicating that the compound is free of unbound moisture. To aid discussion, the TGA data are examined in four zones. Mass losses in Zones A and B for both samples were similar, but mass losses in Zone $\mathrm{C}$ and particularly in Zone D increased significantly in sample (II) relative to sample (I). As we show below, the difference between mass loss values for this material can be assigned to the atmospheric moisture content, which changes the decomposition mechanism.

To uncover the processes that occur during the transformation of $\mathrm{Zn}_{5}(\mathrm{OH})_{8} \mathrm{Cl}_{2} \cdot \mathrm{H}_{2} \mathrm{O}$ to $\mathrm{ZnO}$, in situ real-time synchrotron radiation XRD studies were undertaken. Data were collected while heating $\mathrm{Zn}_{5}(\mathrm{OH})_{8} \mathrm{Cl}_{2} \cdot \mathrm{H}_{2} \mathrm{O}$ from 26 to $600{ }^{\circ} \mathrm{C}$, which revealed the crystalline intermediate phases, Fig. 4 (see also ESI Fig. S4 and S5†).

The first transformation occurred from 100 to $161{ }^{\circ} \mathrm{C}$, where the intensities of the initial diffraction pattern decrease.
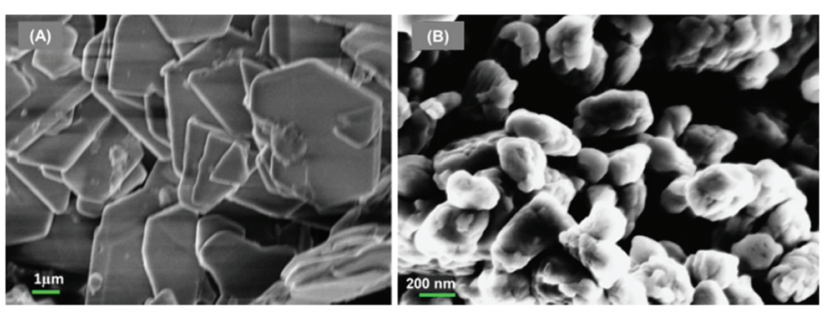

Fig. 2 SEM images of (A) $\mathrm{Zn}_{5}(\mathrm{OH})_{8} \mathrm{Cl}_{2} \cdot \mathrm{H}_{2} \mathrm{O}$ and (B) $\mathrm{ZnO}$ made from the material shown in (A). 


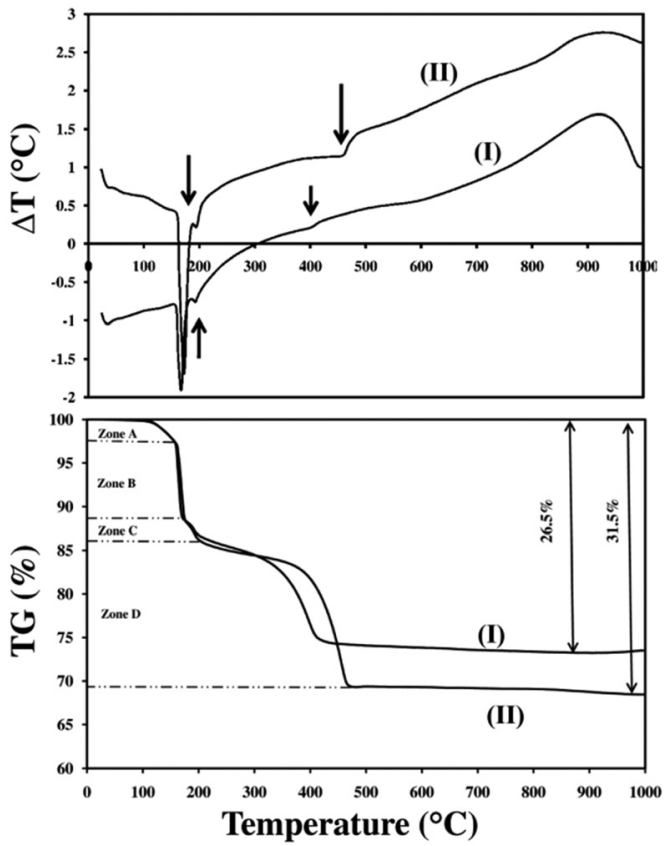

Fig. 3 TGA-DTA of $\mathrm{Zn}_{5}(\mathrm{OH})_{8} \mathrm{Cl}_{2} \cdot \mathrm{H}_{2} \mathrm{O}$. (I) freshly made $\mathrm{Zn}_{5}(\mathrm{OH})_{8} \mathrm{Cl}_{2} \cdot \mathrm{H}_{2} \mathrm{O}$, (II) $\mathrm{Zn}_{5}(\mathrm{OH})_{8} \mathrm{Cl}_{2} \cdot \mathrm{H}_{2} \mathrm{O}$ tested after 13 months of aging.
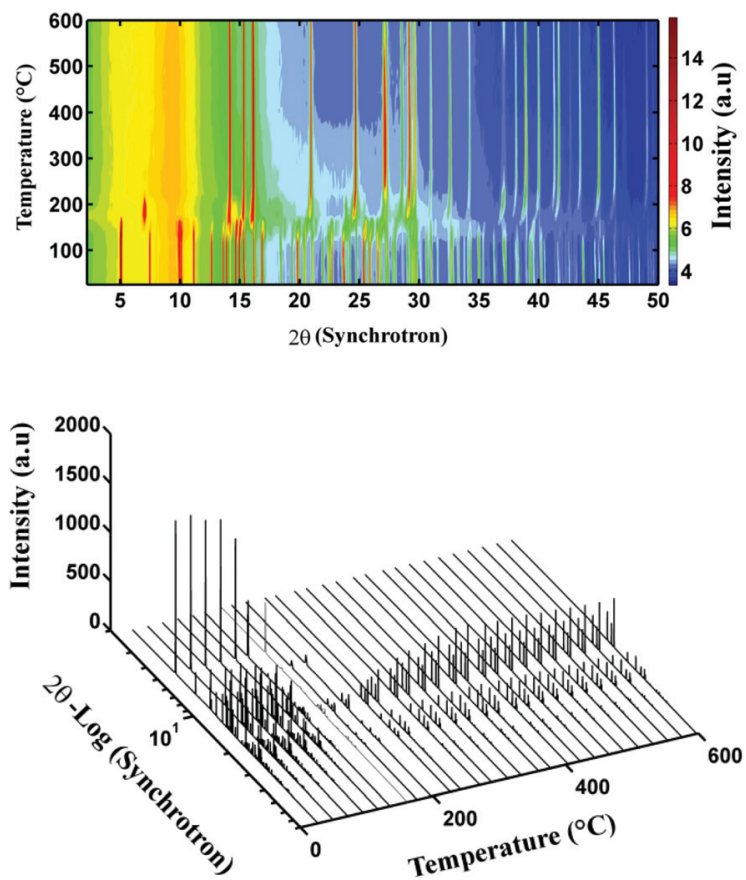

Fig. 4 (Top) Colour-coded contour graph showing powder XRD data collected from $\mathrm{Zn}_{5}(\mathrm{OH})_{8} \mathrm{Cl}_{2} \cdot \mathrm{H}_{2} \mathrm{O}$ sample during in situ experiment between 26 and $600{ }^{\circ} \mathrm{C}$. (Bottom) Sequence of XRD patterns showing the development of diffraction peaks associated with $\mathrm{ZnO}$.

This process is assigned to a dehydration process, eqn (1), and is consistent with Zone A in the TGA data.

$$
\mathrm{Zn}_{5}(\mathrm{OH})_{8} \mathrm{Cl}_{2} \cdot \mathrm{H}_{2} \mathrm{O}_{(\mathrm{cr})} \stackrel{100-161^{\circ} \mathrm{C}}{\rightleftharpoons} \mathrm{Zn}_{5}(\mathrm{OH})_{8} \mathrm{Cl}_{2(\mathrm{cr})}+\mathrm{H}_{2} \mathrm{O}_{(\mathrm{g})}
$$

The next transformation occurred in the region of 161-197 ${ }^{\circ} \mathrm{C}$ where the peaks associated with $\mathrm{Zn}_{5}(\mathrm{OH})_{8} \mathrm{Cl}_{2}$ disappear and peaks assigned to $\mathrm{ZnO}$ appear together with those of $\mathrm{ZnO} \cdot \mathrm{ZnCl}_{2} \cdot 2 \mathrm{H}_{2} \mathrm{O}$, a lower order zinc hydroxide chloride. This process is described in eqn (2). Although others have reported on the probable formation of $\beta-\mathrm{Zn}(\mathrm{OH}) \mathrm{Cl},{ }^{8,9,12}$ the XRD data collected in the present work indicate that $\mathrm{ZnO} \cdot \mathrm{ZnCl}_{2} \cdot 2 \mathrm{H}_{2} \mathrm{O}$ is the intermediate crystalline phase in this temperature range. The TGA-DTA data, Fig. 3, reveal an endothermic peak corresponding to a decomposition at $\sim 164{ }^{\circ} \mathrm{C}$ with the associated 3 moles of water released up to a temperature of $\sim 200^{\circ} \mathrm{C}$ (Zones A and B in the TGA graph) consistent with the combination of eqn (1) and (2).

$$
\mathrm{Zn}_{5}(\mathrm{OH})_{8} \mathrm{Cl}_{2(\mathrm{cr})} \stackrel{161-197^{\circ} \mathrm{C}}{\rightleftharpoons} 3 \mathrm{ZnO}+\mathrm{ZnO} \cdot \mathrm{ZnCl}_{2} \cdot 2 \mathrm{H}_{2} \mathrm{O}_{(\mathrm{cr})}+2 \mathrm{H}_{2} \mathrm{O}_{(\mathrm{g})}
$$

At higher temperatures, only one more transformation in the synchrotron XRD data was evident: all the peaks except for those assigned to $\mathrm{ZnO}$ disappear. This transformation occurs in the temperature range $197-225{ }^{\circ} \mathrm{C}$, and coincides with the mass loss in Zone C. Up to $400{ }^{\circ} \mathrm{C}$, the intensity of the $\mathrm{ZnO}$ diffraction peaks increases whereupon no further changes are observed up to the final measurement temperature of $600{ }^{\circ} \mathrm{C}$. Importantly, while the XRD data indicate that $\mathrm{ZnO}$ is the only crystalline material present at temperatures greater than $225^{\circ} \mathrm{C}$, TGA indicates that significant mass is lost beyond this temperature, Zone D (ESI, Fig. S6 and S7 $\dagger$ ). When considered in conjunction with mass spectrometry data (discussed below), we can assign this mass loss to decomposition of an amorphous phase, $\mathrm{Zn}(\mathrm{OH})_{2} \cdot \mathrm{ZnCl}_{2}$, formed by rearrangement and dehydration of the crystalline intermediate $\mathrm{ZnO} \cdot \mathrm{ZnCl}_{2} \cdot 2 \mathrm{H}_{2} \mathrm{O}$ according to eqn (3). We note that examples of zinc compounds (e.g., zinc borate, $x \mathrm{ZnO} \cdot y \mathrm{~B}_{2} \mathrm{O}_{3} \cdot z \mathrm{H}_{2} \mathrm{O}$ ) exist with either crystalline or amorphous structures based on the synthesis method and temperature. Such compounds can retain water up to temperatures of $\sim 400{ }^{\circ} \mathrm{C} .{ }^{18,19}$ In addition, amorphous materials have been reported when other layered hydroxide salts are calcined at temperatures of $300-500{ }^{\circ} \mathrm{C} .{ }^{20-22} \mathrm{We}$ discount the possibility of the formation and melting of $\mathrm{ZnCl}_{2}$ as this would imply that no further release of water should occur, which is in contrast to our mass spectrometry data (see below).

$$
\mathrm{ZnO} \cdot \mathrm{ZnCl}_{2} \cdot 2 \mathrm{H}_{2} \mathrm{O} \stackrel{197-225{ }^{\circ} \mathrm{C}}{\rightleftharpoons} \mathrm{Zn}(\mathrm{OH})_{2} \cdot \mathrm{ZnCl}_{2}+\mathrm{H}_{2} \mathrm{O}_{(\mathrm{g})}
$$

Interpretation of the last stage of decomposition, after which only ZnO remains, is not straightforward and, as shown in Fig. 3, mass loss can be variable. The major reaction involved is the decomposition of amorphous $\mathrm{Zn}(\mathrm{OH})_{2} \cdot \mathrm{ZnCl}_{2}$ to $\mathrm{ZnO}$ with the release of $\mathrm{HCl}$, eqn (4). DTA shows an endothermic peak corresponding to this process at $\sim 400{ }^{\circ} \mathrm{C}$.

$$
\mathrm{Zn}(\mathrm{OH})_{2} \cdot \mathrm{ZnCl}_{2} \text { (amorphous) } \stackrel{T>400{ }^{\circ} \mathrm{C}}{\longrightarrow} 2 \mathrm{ZnO}+2 \mathrm{HCl}_{(\mathrm{g})}
$$

Considering the previous work of Kozawa et al. ${ }^{13}$ (discussed above) the variable thermal decomposition behaviour of the 
$\mathrm{Zn}_{5}(\mathrm{OH})_{8} \mathrm{Cl}_{2} \cdot \mathrm{H}_{2} \mathrm{O}$ is a consequence of variable amounts of volatile zinc-containing species being formed which are, in turn, dependent on the moisture content of the atmosphere under which the material is decomposed. In particular, anhydrous zinc chloride is implicated in this process. Our attempts to identify zinc chloride released from $\mathrm{Zn}_{5}(\mathrm{OH})_{8} \mathrm{Cl}_{2} \cdot \mathrm{H}_{2} \mathrm{O}$ upon heating using TGA-MS experiments (ESI Fig. S8-S10†) were inconclusive due to instrumental limitations although experiments confirmed that water was released at temperatures up to $\sim 230{ }^{\circ} \mathrm{C}$ with $\mathrm{MS}$ peaks associated with the TGA zones A, B and $\mathrm{C}$, and that hydrogen chloride was evolved at temperatures corresponding to Zone D. However, anhydrous zinc chloride was unambiguously identified as a volatile reaction product in experiments where $\mathrm{Zn}_{5}(\mathrm{OH})_{8} \mathrm{Cl}_{2} \cdot \mathrm{H}_{2} \mathrm{O}$ was heated in a sublimation apparatus (ESI, Fig. S11a and $\mathrm{b} \dagger$ ). Powder XRD patterns were collected for the sublimate using a diffractometer stage that was heated at $100-120^{\circ} \mathrm{C}$ to avoid hydration of the moisture-sensitive material. The diffraction pattern revealed that the sublimate is a mixture of $\alpha-\mathrm{ZnCl}_{2}$ (JC-PDF: 01-074-0519) and $\beta-\mathrm{ZnCl}_{2}$ (JC-PDF: 01-072-1284), Fig. 5. No peak associated with $\beta-\mathrm{Zn}(\mathrm{OH}) \mathrm{Cl}$ was detected.

TGA-DTA of the obtained $\mathrm{ZnCl}_{2}$ recorded under a flow of air revealed a mass gain of $\sim 1 \%$ from room temperature up to $\sim 50{ }^{\circ} \mathrm{C}$ (in agreement with the hygroscopic nature of $\mathrm{ZnCl}_{2}$ ), and a subsequent mass loss of $\sim 99.3 \%$ upon heating to $1000{ }^{\circ} \mathrm{C}$. TGA-DTA of zinc chloride dihydrate was conducted for comparison and the data are significantly different to those of the collected $\mathrm{ZnCl}_{2}$ (ESI Fig S12 $\dagger$ ). It is apparent that greater mass loss occurs with the more dehydrated zinc chloride species. Examination of the mechanism of decomposition of hydrated zinc chloride from previous work ${ }^{9,23}$ is illustrative in this context. Heating hydrated zinc chloride does not directly form dehydrated zinc chloride but rather $\mathrm{ZnO}$, eqn (5), or $\mathrm{Zn}$ $(\mathrm{OH}) \mathrm{Cl}$, eqn (6) that may subsequently decompose to $\mathrm{ZnO}$ or

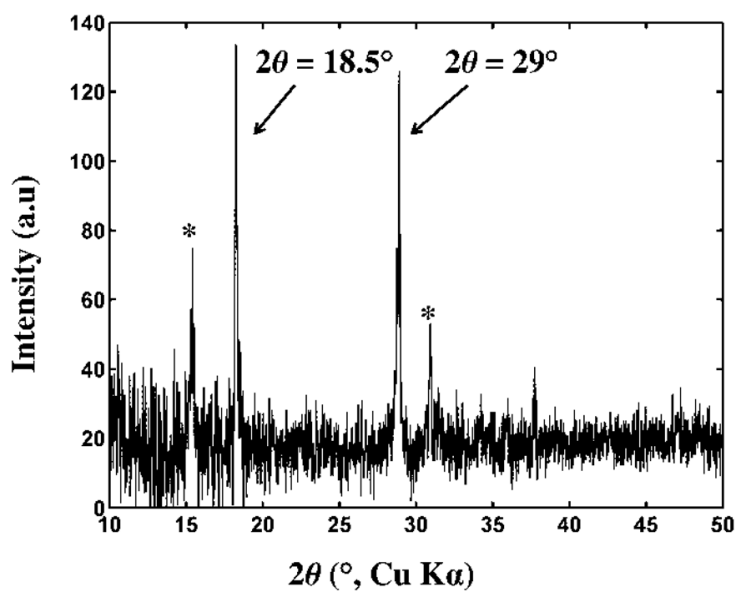

Fig. 5 Powder XRD data collected at $100-120{ }^{\circ} \mathrm{C}$ for the sublimate obtained from heated $\mathrm{Zn}_{5}(\mathrm{OH})_{8} \mathrm{Cl}_{2} \cdot \mathrm{H}_{2} \mathrm{O}$. Peaks marked with * are assigned to $\beta-\mathrm{ZnCl}_{2}$ (JC-PDF: 01-072-1284) and the remainder are assigned to $\alpha-\mathrm{ZnCl}_{2}$ (JC-PDF: 01-074-0519) with major peaks located at $2 \theta=18.5^{\circ}$ and $29^{\circ}$.
$\mathrm{ZnCl}_{2}$. On the other hand anhydrous zinc chloride can volatilise when heated, eqn (7).

$$
\begin{gathered}
\mathrm{ZnCl}_{2(\mathrm{~g})}+2 \mathrm{H}_{2} \mathrm{O} \stackrel{\text { cooling }}{\longrightarrow} \mathrm{ZnCl}_{2} \cdot 2 \mathrm{H}_{2} \mathrm{O} \stackrel{\text { heat }}{\longrightarrow} \mathrm{ZnO}+2 \mathrm{HCl}_{(\mathrm{g})}+\mathrm{H}_{2} \mathrm{O}_{(\mathrm{g})} \\
\mathrm{ZnCl}_{2} \cdot 2 \mathrm{H}_{2} \mathrm{O} \stackrel{\text { heat }}{\longrightarrow} \beta-\mathrm{Zn}(\mathrm{OH}) \mathrm{Cl}+\mathrm{HCl}_{(\mathrm{g})}+\mathrm{H}_{2} \mathrm{O}_{(\mathrm{g})} \\
\text { Anhyd. } \mathrm{ZnCl}_{2(\mathrm{~s})} \stackrel{\text { heat }}{\longrightarrow} \mathrm{ZnCl}_{2(\mathrm{l})} \stackrel{\text { heat }}{\longrightarrow} \mathrm{ZnCl}_{2(\mathrm{~g})}
\end{gathered}
$$

It is apparent that anhydrous $\mathrm{ZnCl}_{2}$ can be formed by heating $\mathrm{Zn}_{5}(\mathrm{OH})_{8} \mathrm{Cl}_{2} \cdot \mathrm{H}_{2} \mathrm{O}$, eqn (8), but the amount of $\mathrm{ZnCl}_{2}$ formed will depend on the moisture content of the atmosphere under which $\mathrm{Zn}_{5}(\mathrm{OH})_{8} \mathrm{Cl}_{2} \cdot \mathrm{H}_{2} \mathrm{O}$ is thermally decomposed. If the moisture content of the atmosphere in which reaction occurs increases, the amount of volatile $\mathrm{ZnCl}_{2}$ decreases. That is, higher atmospheric moisture favours eqn (4) compared to eqn (8), and vice versa. Therefore, higher atmospheric moisture favours $\mathrm{ZnO}$ production (closer to the theoretical 5 moles of $\mathrm{ZnO}$ for every mole of $\mathrm{Zn}_{5}(\mathrm{OH})_{8} \mathrm{Cl}_{2} \cdot \mathrm{H}_{2} \mathrm{O}$ decomposed). On the other hand, in dry atmospheres some zinc chloride will be volatilised and the yield of $\mathrm{ZnO}$ will be reduced. These findings are reflected in the variable TGA mass loss values.

$$
\mathrm{Zn}(\mathrm{OH})_{2} \cdot \mathrm{ZnCl}_{2} \text { (amorphous) } \stackrel{T>400^{\circ} \mathrm{C}}{\rightleftharpoons} \mathrm{ZnO}+\mathrm{ZnCl}_{2(\mathrm{~g})}+\mathrm{H}_{2} \mathrm{O}
$$

From the data obtained in the experiments described above, we can now propose a mechanism for the thermal decomposition of $\mathrm{Zn}_{5}(\mathrm{OH})_{8} \mathrm{Cl}_{2} \cdot \mathrm{H}_{2} \mathrm{O}$ to $\mathrm{ZnO}$, Scheme 1 . Importantly, this mechanism accounts for the moisture dependent pathway that may lead to sub-optimal yields of $\mathrm{ZnO}$.

Incidentally, in the current work the presence or absence of the zinc oxychloride species $\mathrm{Zn}_{2} \mathrm{OCl}_{2}$ was not confirmed. This compound had been reported by others ${ }^{24}$ and thus we cannot discount a side reaction involved in the system according to reaction (9).

$$
\mathrm{Zn}(\mathrm{OH})_{2} \cdot \mathrm{ZnCl}_{2}(\text { amorphous }) \stackrel{T>400{ }^{\circ} \mathrm{C}}{\rightleftharpoons} \mathrm{Zn}_{2} \mathrm{OCl}_{2(\mathrm{~g})}+\mathrm{H}_{2} \mathrm{O}_{(\mathrm{g})}
$$

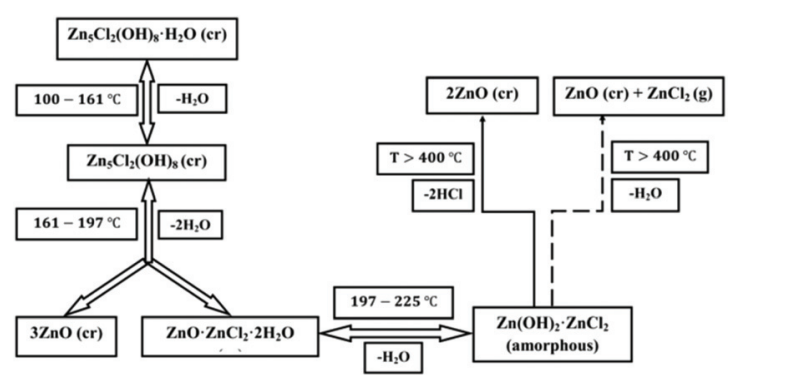

Scheme 1 Schematic of the proposed mechanism for the thermal transformation of $\mathrm{Zn}_{5}(\mathrm{OH})_{8} \mathrm{Cl}_{2} \cdot \mathrm{H}_{2} \mathrm{O}$ into $\mathrm{ZnO}$. The dashed arrow indicates a reaction that is moisture dependent, which is responsible for the excess of mass loss during some TGA experiments. 


\section{Conclusions}

In this work, we examined the thermal decomposition of zinc hydroxide chloride monohydrate, $\mathrm{Zn}_{5}(\mathrm{OH})_{8} \mathrm{Cl}_{2} \cdot \mathrm{H}_{2} \mathrm{O}$, into $\mathrm{ZnO}$ and the sequence of changes occurring in the process. Crystalline zinc oxide particles with BET specific surface area of $1.3 \mathrm{~m}^{2} \mathrm{~g}^{-1}$ were formed by thermal decomposition of zinc hydroxide chloride monohydrate sheets. The specific surface area of the resultant zinc oxide is lower than that of the commercially available French process $\mathrm{ZnO}\left(\sim 3-5 \mathrm{~m}^{2} \mathrm{~g}^{-1}\right)$. The mechanism of decomposition of zinc hydroxide chloride monohydrate was examined in detail and found to proceed via the formation of $\mathrm{ZnO} \cdot \mathrm{ZnCl}_{2} \cdot 2 \mathrm{H}_{2} \mathrm{O}$ and $\mathrm{ZnCl}_{2}$ intermediates. The formation of anhydrous zinc chloride under moisture-free conditions was demonstrated by collection and post analysis of material deposited on cooler areas of the reaction apparatus. Therefore, the discrepancies in the literature can be resolved by noting that the mechanism of conversion of zinc hydroxide chloride monohydrate to zinc oxide is dependent on the relative humidity of the atmosphere under which the process occurs and the degree to which the $\mathrm{ZnCl}_{2}$ intermediate is hydrolysed to $\mathrm{ZnO}$.

\section{Acknowledgements}

This work was supported by PT. Indo Lysaght (Indonesia). We also thank Mr Jean-Pierre Guerbois (TGA-MS), Dr R. Wuhrer (scanning electron microscopy) Ms Verena Schrameyer (translation of German papers) and the Australian Synchrotron, Melbourne, Victoria (Powder Diffraction beamline).

\section{Notes and references}

1 A. Moezzi, A. M. McDonagh and M. B. Cortie, Chem. Eng. J., 2012, 185-186, 1-22.

2 K. Sokołowski, I. Justyniak, W. Bury, J. Grzonka, Z. Kaszkur, Ł. Ma colski, M. Dutkiewicz, A. Lewalska, E. b. Krajewska, D. Kubicki, K. Wûjcik, K. J. Kurzydłowski and J. Lewinski, Chem. - Eur. J., 2015, 21, 5488-5495.

3 A. Moezzi, M. Cortie, A. Dowd and A. McDonagh, J. Nanopart. Res., 2014, 16, 2344.
$4 \mathrm{M}$. Sorel, Comptes rendus hebdomadaires des séances de l'Académie des sciences, 1855, 41, 784-785.

5 O. K. Srivastava and E. A. Secco, Can. J. Chem., 1967, 45, 579-583.

6 J. W. Hoffman and I. Lauder, Aust. J. Chem., 1968, 21, 1439-1443.

7 C. A. Sorrell, J. Am. Ceram. Soc., 1977, 60, 217-220.

8 I. Rasines and J. I. Morales de Setién, Thermochim. Acta, 1980, 37, 239-246.

9 O. Garcia-Martinez, E. Vila, J. L. Martin de Vidales, R. M. Rojas and K. Petrov, J. Mater. Sci., 1994, 29, 54295434.

10 M. Krunks, J. Madarász, T. Leskelä, A. Mere, L. Niinistö and G. Pokol, J. Therm. Anal. Calorim., 2003, 72, 497506.

11 W. Zhang and K. Yanagisawa, Chem. Mater., 2007, 19, 2329-2334.

12 H. Tanaka and A. Fujioka, Mater. Res. Bull., 2010, 45, 46-51.

13 T. Kozawa, A. Onda, K. Yanagisawa, A. Kishi and Y. Masuda, J. Solid State Chem., 2011, 184, 589-596.

14 A. Shaporev, V. Ivanov, A. Baranchikov, O. Polezhaeva and Y. Tret'yakov, Russ. J. Inorg. Chem., 2007, 52, 18111816.

15 A. Moezzi, M. Cortie and A. McDonagh, Dalton Trans., 2011, 40, 4871-4878.

16 A. Moezzi, A. McDonagh, A. Dowd and M. Cortie, Inorg. Chem., 2013, 52, 95-102.

17 A. Moezzi, M. B. Cortie and A. M. McDonagh, Dalton Trans., 2013, 42, 4432-14437.

18 D. M. Schubert, US Patent, 5l342553, 1994.

19 Y.-H. Gao, Z.-H. Liu and X.-L. Wang, J. Chem. Thermodyn., 2009, 41, 775-778.

20 V. Rives, Mater. Chem. Phys., 2002, 75, 19-25.

21 F. M. Labajos, V. Rives and M. A. Ulibarri, J. Mater. Sci., 1992, 27, 1546-1552.

22 M. K. Ram Reddy, Z. P. Xu, G. Q. Lu and J. C. Diniz da Costa, Ind. Eng. Chem. Res., 2006, 45, 7504-7509.

$23 \mathrm{~J}$. E. House and K. A. House, Descriptive Inorganic Chemistry, Academic Press, London, 2010.

24 S. H. Son and F. Tsukihashi, J. Phys. Chem. Solids, 2005, 66, 392-395. 